\title{
Ampulla of Vater
}

National Cancer Institute

\section{Source}

National Cancer Institute. Ampulla of Vater. NCI Thesaurus. Code C13011.

The junction of the common bile and main pancreatic ducts, which protrudes into the medial aspect of the descending duodenum at the major duodenal papilla. The flow of bile and pancreatic juices into the duodenum through the Ampulla of Vater is controlled by the sphincter of Oddi. 